\section{Book Review: Let the Children Play: How More Play Will Save Our Schools and Help Children Thrive}

Excelsior: Leadership in Teaching and Learning 2021, Vol. 14(1), 61-63 (C) The Author 2021 CC-BY 4.0 International Reprints and permissions: surface.syr.edu/excelsior https://doi.org/10.14305/in.1944 $\underline{0413.2021 .14 .1 .05}$ nyacte.org

\title{
(D) Kate Hoskins ${ }^{1}$ and (1D Sue Smedley ${ }^{2}$
}

\section{Keywords}

book review, play, early years, standardization, reform

Sahlberg, P., \& Doyle, W. (2019). Let the children play: How more play will save our schools and help children thrive. Oxford University Press. ISBN: 9780190930967

Rooted in a passionate belief in the importance of play, Sahlberg and Doyle have written a persuasive manifesto. In essence, they argue that worksheet-oriented learning and standardized testing represent "a theft from children" (p. 8). Children need rich opportunities for play that is self-directed, imaginative, creative, and physical. Their argument is endorsed in a powerful foreword about "real play" by Sir Ken Robinson, an acclaimed advocate of education and creativity.

This is far from an ordinary textbook about play. Sahlberg and Doyle often directly address the reader and engage in gripping and emotionally-charged discussions. Play is dying, they claim, and a major reason for this is the "Global Education Reform Movement" (GERM), which prioritises competition, testing and outcomes over play, engagement and even children's well-being. In their view, GERM is a seriously misguided attempt to raise standards in schools, children's achievements and ultimately their competitiveness as employees in a global economy. How ironic, they note, that world business leaders in 2016 identified creativity, emotional intelligence and negotiation as core skills needed for the 21 st century. These are all skills developed through play (pp. 72-73).

Sahlberg and Doyle also critique the 1988 reforms to the education system in England-reforms which included unprecedented external control of what was taught in schools and how it was taught, along with a focus on school choice, data, and testing. However, as the authors argue, "Standardization is

\footnotetext{
${ }^{1}$ Brunel University London

2 University of Roehampton
}

Corresponding Author:

Kate Hoskins, Brunel University London, Department of Education, Gaskel Building 609, Kingston Lane, Uxbridge, Middlesex UB8 3PH Great Britain Email: kate.hoskins@brunel.ac.uk 
not the same as having high standards in education" (p. 102), and the constraints imposed on teachers limited their creativity, experimentation, and playfulness as well as that of their pupils.

In discussing the nature of play, the authors acknowledge the complexity of the concept, referring to classic texts by Moyles (1989) and Froebel (see Tovey, 2016), the founder of the kindergarten and advocate of play and a developmentally appropriate curriculum. The authors also clearly define play as a "biological imperative" (p. 44). This leads into an important theme which could be voiced more loudly in debates about education. Play is important for children as they grow older too, including young adults at colleges and universities.

We seem to be a very long way away from the Golden Age of Childhood imagined by the authors. Sometime in the future, a curriculum founded on play will mean children can attend a "Failure Academy" (p. 12), where they will be encouraged to experiment, take risks, and make mistakes in an environment in which mistakes are not 'demonized' (p. 140).

The global perspective of this book is an important dimension and adds a helpful counterweight to generalisations about play and learning. There is also acknowledgement of the impact of poverty, belonging to a minority group, or having disabilities. The authors argue that members of marginalised groups are urgently in need of quality play opportunities.

In later chapters, the authors argue that play has been sabotaged in America, evidenced through the loss of recess and the endless scheduling many children face. Without recess, playgrounds are left empty and young people have little space for "joy" (p. 174). They note the ways in which parents buy into the "death of recess" in the quest to academically fast track their children.

The phenomenon of over-scheduling children can be a source of stress and strain for families. The authors note the example of Jeff, a father committed to ensuring every moment of his son's time is timetabled during the school summer holidays (p. 195). Reading the proposed schedule facing Jeff's son was exhausting, so one can only imagine how hard it might be to live through it. The impact that might be created by the loss of recess and over-scheduling children is yet to become fully apparent, a point the authors could perhaps have explored further.

The authors' reflections on the "global war on play" (p. 197) provide some interesting points about how most countries in the world are now reducing the time available to children for play. China is identified as a leading offender, but other East Asian countries are not far behind. The increase in standardised testing is identified as a key factor in driving the over-emphasis on academic work at the cost of providing time and space to play.

But despite several chapters of significant critique about approaches to play in the Global North and South, the book ends on a more positive note. Attention is given to "Great Play Experiments" (p. 214), including the Finnish example that reveals the value and benefit of a discourse of equality, enacted through fair funding. Professionalism, teacher education and a societal respect for teaching, combine with this discourse of equality to provide excellent opportunities for children to thrive. The mantras that form the basis of the earlier chapters in this book evidently stem from Finland, where "let children be children" and "the children must play" (p. 217) dominate in settings and are in common use amongst parents and teachers.

The threads of book are drawn together in chapter ten through a discussion about what the schools of tomorrow, across the world, could look like if play were prioritised. There is cause for optimism. The book ends with a discussion focused on the good practice and exciting projects currently running and the areas where these projects could grow in the future.

In coming to the end of the book, we pondered the likely audience for this text. We recognise the Eurocentric views that tend to dominate this book and serve to elevate a version of childhood grounded in particular white and middle-class interpretations of an imagined vision of idealised child development and contextualised in the global north. With this caveat in mind, the book is certainly of interest to academics and practitioners who, we suspect, would largely agree with many of the arguments made. 
Parents, too, are likely to find useful insights. Some may well pause to consider if and how they are overtimetabling their own children and the potential impact of doing so. Students will also enjoy this text, although some may find it challenging to navigate the discursive style of writing and lack of signposting to the overall argument being made. It is certainly a book that policy makers should read. It might compel them to enact significant changes to our education systems.

\section{Declaration of Conflicting Interests}

The author declared no potential conflicts of interest with respect to the research, authorship, and/or publication of this article.

\section{Funding}

The authors received no financial support for this research.

\section{ORCID iD}

Katie Hoskins (D) https://ocrid.org/0000-0001-6360-8898

Sue Smedley (iD http://ocrid.org/0000-0002-9937-0866

\section{References}

Myles, J. (1989). Just playing? Role and status of play in early childhood education. Open University Press

Tovey, Helen (2016). Bringing the Froebel approach to your early years practice. Routledge. https://doi.org/10.4324/9781315617190 